\title{
Carbon Stocks and Soil Organic Matter Quality Under Different of Land Uses in the Maranhense Amazon
}

\author{
Victor Roberto Ribeiro Reis ${ }^{1}$, Diana Signor Deon ${ }^{2}$, Luciano Cavalcante Muniz ${ }^{1}$, Marlen Barros e Silva ${ }^{1}$, \\ Carlos Augusto Rocha de Moraes Rego ${ }^{3}$, Uelson Serra Garcia ${ }^{4}$, Ilka South de Lima Cantanhêde ${ }^{5}$ \\ \& Joaquim Bezerra Costa ${ }^{2}$ \\ ${ }^{1}$ Maranhão State University (UEMA), São Luís, Brazil \\ ${ }^{2}$ Brazilian Agricultural Research Corporation (EMBRAPA), Brasília, Brazil \\ ${ }^{3}$ West State University of Paraná (UNIOESTE), Marechal Candido Rondon, Brazil \\ ${ }^{4}$ Federal University of Goiás (UFG), Goiânia, Brazil \\ ${ }^{5}$ Federal Institute of Education, Science and Technology of Maranhão (IFMA), São Luís, Brazil \\ Correspondence: Victor Roberto Ribeiro Reis, Maranhão State University (UEMA), São Luís, Brazil. Tel: \\ 55-87-98828-1588. E-mail: victorribeiroagro@gmail.com
}

$\begin{aligned} & \text { Received: February 9, } 2018 \quad \text { Accepted: March 11, } 2018 \quad \text { Online Published: April 15, } 2018 \\ & \text { doi:10.5539/jas.v10n5p329 }\end{aligned} \quad$ URL: https://doi.org/10.5539/jas.v10n5p329

The research is financed by FAPEMA, UEMA and EMBRAPA.

\begin{abstract}
In the face of the traditional model of succession of native environments in pastures or agricultural areas, followed by superpastejo and the concern with emissions of greenhouse gases in the Brazilian Amazon region, this work aims to determine the influence of different land uses on carbon sequestration and soil organic matter changes in the municipality of Pindaré-Mirim, in state of Maranhão. This study evaluated different uses of the soil: native forest; secondary vegetation (capoeira); degraded pasture and CLFI (Crop-Livestock-Forest Integration) system. The deformed and undisturbed samples were collected at depths: $0.00-0.10,0.10-0.20$, $0.20-0.30,0.30-0.40,0.40-0.60,0.60-0.80$ and $0.80-1.00 \mathrm{~m}$. Soil densities were determined by the volumetric ring method, the carbon stocks by the carbon content in the soil evaluating the dry combustion, and the accumulated carbon stocks were calculated in $1.00 \mathrm{~m}$. The physical fractions of the organic matter were determined by means of the granulometric method. At depth $0.0-0.10 \mathrm{~m}$, the soil density in the native forest (1.17 $\left.\mathrm{g} \mathrm{cm}^{-3}\right)$ was lower than the average of degraded pasture $\left(1.40 \mathrm{~g} \mathrm{~cm}^{-3}\right)$. There was no difference in the carbon content between all the land uses up to $0.40 \mathrm{~m}$ depth. The accumulated carbon stocks up to $1.00 \mathrm{~m}$ ranged from 49.52 $\mathrm{Mg} \mathrm{ha}^{-1}$ to $64.41 \mathrm{Mg} \mathrm{ha}^{-1}$ and were higher in the native forest compared to capoeira and the ICLF system. In relation to the accumulated carbon stock, the native forest and degraded pasture were the ones that obtained the highest levels, followed by the capoeira and the CLFI system.
\end{abstract}

Keywords: fractionation of organic matter, degraded grassland, low carbon agriculture

\section{Introduction}

In the municipality of Pindaré-Mirim and other regions of Amazonia, the practice of converting native forests to pastures for traditional cattle ranching or agricultural areas, which rapidly reach the stage of degradation, is predominant. The degradation of pasture is one of the main agronomic problems for the cattle activity, occupying $90 \%$ of the total pasture area of the Brazilian Northeast (DIEESE, 2011; Dias-Filho, 2014) and contributing to increased emissions of greenhouse gases (GHGs) such as methane, nitrous oxide and carbon dioxide.

In 2015, at the 21st United Nations Conference on Climate Change (COP-21), held in Paris, France, Brazil committed to reduce GHGs emissions by 37 percent until 2025 and by 43 percent, until 2030 (La Rovere, 2017). To this end, the country also intends to clear deforestation in the Legal Amazon and restore 12 million hectares of forests by 2030, through diversification of agricultural production and the recovery of degraded pastures.

In order to recover or reform degraded pastures, the diversified or integrated Crop-Livestock-Forest (CLFI) systems are a set of strategies that integrate agricultural, livestock and forestry activities in synergy in the same 
area, under intercropping, succession or rotation (Balbino et al., 2012). These systems bring several global and local environmental benefits, such as soil and water conservation, carbon sequestration, cash flow flexibility throughout the year and increased biodiversity.

These changes in the configuration of the production system have a direct impact on soil organic matter quality, one of the largest terrestrial carbon reservoirs. The dynamics of organic matter is driven by the addition of organic residues of various natures and by the continuous transformation under the action of biological, chemical and physical factors. Signor et al. (2014) explain that these changes in soil organic matter can be measured by changes in soil $\mathrm{C}$ stock and in its chemical or physical fractions or combinations thereof.

The Maranhão Amazon has a rich biodiversity, occupying 26\% of the Amazonian biome, with 62 municipalities, including the municipality of Pindaré-Mirim. However, for years this region has been suffering with deforestation, illegal logging, mining, coal production, over hunting and cattle breeding. According to information from the PRODES System, from the National Institute of Space Research, Brazil (INPE), until 2010 $71.05 \%$ of the State had been deforested. Today, less than $25 \%$ of its original vegetation remains in the Maranhão Amazon (INPE, 2017).

It is known that the traditional model of succession of native environments in pastures or agricultural areas, followed by superpastejo in the Amazon region of the State of Maranhão is a reality. Based on this, Brazil's commitment aims to implement an integration system to reduce GHGs emissions. Thus, this work is based on the hypothesis that the crop-livestock-forest integration system provides the replacement and protection of organic matter in the soil, due to the biomass maintenance of grasses and pruning of the forest component, in addition to the greater volume of roots not alone. The objective of this work was to determine the influence of different land uses on soil carbon sequestration and qualitative changes in soil organic matter, in the municipality of Pindaré-Mirim, in the Amazonian biome of the state of Maranhão.

\section{Materials and Methods}

Soil samples were collected in areas under different uses at the Embrapa Cocais CLFI Technological Reference Unit located in the Pindaré-Mirim municipality, in the Pindaré microregion, with latitude $03^{\circ} 46^{\prime} 13.60^{\prime \prime} \mathrm{S}$, longitude $45^{\circ} 29^{\prime} 42.00^{\prime \prime} \mathrm{W}$ and altitude of 28 meters, in the state of Maranhão. The regional climate according to the classification of Köppen (1948) is Aw (hot and humid), with an annual average temperature of $299.15^{\circ} \mathrm{C}$, minimum annual average of $295.45^{\circ} \mathrm{C}$ and maximum of $306.65 \mathrm{~K}$ (SEPLAN, 2013).

Geologically, the municipality is in the Itapecuru Formation, from Upper Cretaceous, being the soil classified as albaqualf (Santos et al., 2013), with medium texture. As for the relief, it varies from soft-wavy to wavy, originally covered by vegetation of Open Lowland Ombrophylous Forest, with predominance of babassu palm-trees (Attalea speciosa Mart).

This study evaluated four different soil uses within the CLFI Technological Reference Unit at Embrapa Cocais. The areas were:

(I) Native vegetation with babassu, used as a reference area;

(II) Capoeira (secondary vegetation), in natural regeneration for approximately 20 years;

(III) Degraded pasture with Urochloa brizantha cv. Marandu with 15 years of implantation and;

(IV) CLFI, a degraded pasture area in which maize was grown in a consortium with Marandu grass for implantation of the CLFI system, to be managed as recommended by Rego et al. (2017).

In the latter, sampling was done in the first year of the CLFI system, immediately after the maize harvest.

In all areas, the physical and chemical characterization was done up to one meter deep, according to the methodology proposed by Donagema (2011) (Table 1). 
Table 1. Characterization of texture and soil chemistry under different uses evaluated in Maranhense Amazonia, Brazil

\begin{tabular}{|c|c|c|c|c|c|c|c|c|c|c|c|c|c|c|}
\hline Land uses & Depth & Sand & Silt & Clay & $\mathrm{pH}$ & $\mathrm{P}$ & $\mathrm{K}$ & $\mathrm{Al}$ & $\mathrm{Ca}$ & $\mathrm{Mg}$ & $\mathrm{H}+\mathrm{Al}$ & SB & CEC & $\mathrm{V}$ \\
\hline \multirow{8}{*}{ 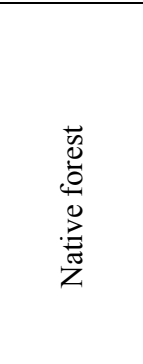 } & ---- m ---- & ------- & $\mathrm{g} \mathrm{kg}^{-1}$ & --------- & $\mathrm{H}_{2} \mathrm{O}$ & $\mathrm{mg} \mathrm{dm}{ }^{-3}$ & \multicolumn{7}{|c|}{ 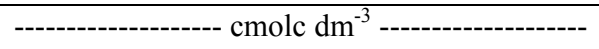 } & $\%$ \\
\hline & $0.00-0.10$ & 748.8 & 144.8 & 106.4 & 4.8 & 1.3 & 0.3 & 2.0 & 2.0 & 4.2 & 6.4 & 6.5 & 12.9 & 50.4 \\
\hline & $0.10-0.20$ & 744.5 & 125.7 & 129.8 & 4.7 & 1.7 & 0.3 & 1.0 & 1.8 & 3.2 & 6.2 & 5.4 & 11.6 & 46.5 \\
\hline & $0.20-0.30$ & 721.4 & 119.8 & 158.8 & 4.7 & 1.7 & 0.3 & 1.8 & 1.5 & 3.1 & 6.7 & 4.9 & 11.6 & 42.5 \\
\hline & $0.30-0.40$ & 693.0 & 128.7 & 178.4 & 4.6 & 0.8 & 0.3 & 2.6 & 1.3 & 1.7 & 6.9 & 3.3 & 10.1 & 32.2 \\
\hline & $0.40-0.60$ & 666.7 & 125.7 & 207.6 & 4.6 & 1.0 & 0.4 & 4.3 & 0.8 & 2.6 & 8.5 & 3.9 & 12.4 & 31.2 \\
\hline & $0.60-0.80$ & 619.5 & 159.8 & 220.7 & 4.6 & 1.3 & 0.4 & 9.1 & 0.5 & 2.9 & 14.9 & 3.9 & 18.8 & 20.8 \\
\hline & $0.80-1.00$ & 615.9 & 165.8 & 218.3 & 4.6 & 0.3 & 0.4 & 12.3 & 0.3 & 3.6 & 20.5 & 4.4 & 24.9 & 17.6 \\
\hline \multirow{7}{*}{ 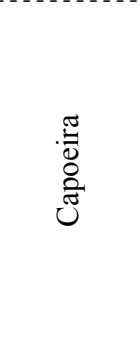 } & $0.00-0.10$ & 768.5 & 107.7 & 123.8 & 5.1 & 1.7 & 0.2 & 1.0 & 1.4 & 3.0 & 6.6 & 4.7 & 11.3 & 41.7 \\
\hline & $0.10-0.20$ & 742.2 & 124.7 & 133.1 & 5.0 & 0.6 & 0.2 & 1.5 & 1.2 & 2.7 & 5.9 & 4.1 & 10.0 & 40.8 \\
\hline & $0.20-0.30$ & 714.3 & 149.6 & 136.2 & 5.1 & 0.7 & 0.2 & 2.4 & 1.1 & 2.4 & 6.5 & 3.8 & 10.2 & 37.0 \\
\hline & $0.30-0.40$ & 706.9 & 123.0 & 170.1 & 5.0 & 0.7 & 0.2 & 3.0 & 0.9 & 2.1 & 7.2 & 3.3 & 10.5 & 31.2 \\
\hline & $0.40-0.60$ & 675.1 & 113.6 & 211.4 & 5.0 & 0.6 & 0.3 & 4.8 & 0.7 & 2.8 & 8.2 & 3.8 & 12.0 & 31.7 \\
\hline & $0.60-0.80$ & 609.5 & 150.5 & 240.0 & 5.1 & 0.3 & 0.3 & 7.3 & 0.7 & 2.9 & 12.3 & 3.9 & 16.2 & 24.2 \\
\hline & $0.80-1.00$ & 602.1 & 145.0 & 252.9 & 5.1 & $*$ & 0.4 & 9.6 & 0.4 & 3.9 & 14.2 & 4.7 & 18.9 & 24.8 \\
\hline \multirow{7}{*}{ 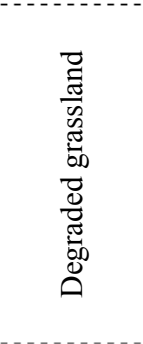 } & $0.00-0.10$ & 528.4 & 411.3 & 60.4 & 5.4 & 3.5 & 1.0 & 0.3 & 3.3 & 6.3 & 2.6 & 10 & 13.3 & 80.8 \\
\hline & $0.10-0.20$ & 630.2 & 274.7 & 95.2 & 5.5 & 1.4 & 0.9 & 0.3 & 3.4 & 5.9 & 2.2 & 10 & 12.6 & 82.2 \\
\hline & $0.20-0.30$ & 647.4 & 257.7 & 95.0 & 5.4 & 1.7 & 0.8 & 0.2 & 3.2 & 7.2 & 2.5 & 11 & 13.8 & 82.1 \\
\hline & $0.30-0.40$ & 584.7 & 263.1 & 152.3 & 5.1 & 1.3 & 0.7 & 1.4 & 3.3 & 1,7 & 3.6 & 15 & 18.4 & 80.7 \\
\hline & $0.40-0.60$ & 537.0 & 301.3 & 161.7 & 4.9 & 1.6 & 0.7 & 4.3 & 2.2 & 7.6 & 5.2 & 11 & 15.8 & 67.0 \\
\hline & $0.60-0.80$ & 557.6 & 292.8 & 149.6 & 4.7 & 1.5 & 0.5 & 8.4 & 1.3 & 76 & 9.2 & 9.5 & 18.7 & 50.6 \\
\hline & $0.80-1.00$ & 537.5 & 317.5 & 145.0 & 4.6 & 1.5 & 0.5 & 11.0 & 0.8 & 6.6 & 10.9 & 8.0 & 18.9 & 42.3 \\
\hline \multirow{7}{*}{$\underset{⿱ 乛}{己}$} & $0.00-0.10$ & 603.6 & 348.2 & 48.2 & 4.8 & 10,7 & 0.9 & 0,3 & 2.7 & 6.3 & 2.2 & 10 & 12.3 & 81.9 \\
\hline & $0.10-0.20$ & 634.2 & 284.9 & 80.9 & 4.9 & 9.3 & 0.8 & 0,6 & 2.8 & 6.2 & 2.4 & 9.9 & 12.3 & 80.6 \\
\hline & $0.20-0.30$ & 614.1 & 293.9 & 92.1 & 4.7 & 7.6 & 0.8 & 1,1 & 2.6 & 6.6 & 3.0 & 10 & 13.1 & 77.4 \\
\hline & $0.30-0.40$ & 583.6 & 306.3 & 110.1 & 4.6 & 4.7 & 0.6 & 4,0 & 2.4 & 6.6 & 4.4 & 9.8 & 14.2 & 69.2 \\
\hline & $0.40-0.60$ & 555.6 & 298.0 & 146.4 & 4.5 & 3.1 & 0.7 & 6,3 & 2.1 & 6.7 & 7.3 & 9.6 & 17.0 & 56.7 \\
\hline & $0.60-0.80$ & 609.7 & 260.8 & 129.5 & 4.5 & 1.2 & 0.7 & 8,9 & 1.1 & 6.4 & 9.7 & 8.3 & 18.0 & 46.4 \\
\hline & $0.80-1.00$ & 581.9 & 312.0 & 106.2 & 4.5 & 1.0 & 0.5 & 10,6 & 0.6 & 6.4 & 9.8 & 7.7 & 17.5 & 43.9 \\
\hline
\end{tabular}

Note. $\mathrm{SB}=$ Sum of bases. ${ }^{*}$ Value below the detection limit of the method.

In each area of use, three trenches of one square meter by one of depth were arranged, randomly arranged in the area. The undisturbed samples for determination of soil density were collected up to one meter deep, comprising seven layers/depths: $0.00-0.10,0.10-0.20,0.20-0.30,0.30-0.40,0.40-0.60,0.60-0.80$ and $0.80-1.00 \mathrm{~m}$ and the three faces (walls) of the trench were sampled at each depth, the soil density was determined by the volumetric ring method, according to the Donagema (2011) methodology. Around the trenches, in all the cardinal directions, twelve equidistant points were marked, where the deformed samples were collected. The twelve deformed soil samples were combined in a composite sample for each depth collected.

The physical granulometric fractionation of soil organic matter was done according to Christensen (1992) and Conceição et al. (2014). This analyzes were carried out in the Laboratory of Soils and Vegetable Tissues of Embrapa Semiárido, using the Elementary Analyzer. The dispersed sample passed through a $75 \mu \mathrm{m}$ sieve. The portion retained in the $75 \mu \mathrm{m}$ sieve represents $\mathrm{C}$ in the form of particulate organic matter that is not trapped in the soil aggregates and is formed by partially decomposed residues. The fraction with size smaller than $75 \mu \mathrm{m}$ has $\mathrm{C}$ in intermediate stage to the advanced stage of decomposition, representing most of the organic $\mathrm{C}$ of the soil and is in the form of organomineral complexes of silt size and clay. After drying, the masses were quantified, ground in a ball mill and the $\mathrm{C}$ contents were determined by dry combustion in elemental analyzer (LECO ${ }^{\circledR} \mathrm{CN}$, 2000). 
From the total $\mathrm{C}$ contents in the soil samples the $\mathrm{C}\left(\mathrm{Mg} \mathrm{ha}^{-1}\right)$ stocks were calculated according to Equation (1), where the "content" is the content of element (C) in soil (\%), soil density in $\mathrm{g} \mathrm{cm}^{-3}$ and "thickness" is the layer thickness for which the stock is being calculated, measured in $\mathrm{m}$ :

$$
\text { Stock }=\text { Content } \times \text { Density } \times \text { Thickness }
$$

However, different types of soils may have different densities, which implies the comparison of different soil masses when considering layers with the same thickness, as those used in the sampling done in this study. Therefore, to compare adequately $\mathrm{C}$ stocks between areas, it was necessary to make comparisons between equal masses of soil, adjusting the values of the depths used in the calculations (Ellert \& Bettany, 1995). This adjustment, called soil mass equivalent correction, was done by taking the native babassu forest as a reference, and consists of finding a new depth value for each area, which will be used in the recalculation of $\mathrm{C}$ stocks, so that the new depth represents the same mass of soil in all areas. The adjustment is made only in the deepest layer to avoid propagation of errors and the corrected depth will be calculated by Equation (2).

$$
\text { Correct Depth }(\mathrm{m})=\left(\mathrm{WED}_{\text {ref }} / \mathrm{WAD}_{\text {cor }}\right) \times \text { Depth }_{\text {cor }}
$$

Where,

$\mathrm{WED}_{\text {ref }}$ represents the weighted average density of the reference area $\left(\mathrm{g} \mathrm{cm}^{-3}\right)$; $\mathrm{WAD}_{\text {cor }}$ is the weighted average density of the area being corrected $\left(\mathrm{g} \mathrm{cm}^{-3}\right)$; Depth ${ }_{\mathrm{cor}}$ is the original depth of the layer being corrected (m).

The values of the parameters were analyzed by Kruskal-Wallis method (non-parametric test), followed by the comparison of means by the Bonferroni test (Dunn) and the confidence intervals around the means were calculated at 95\%. All statistical analyzes were performed using the Action Stat 3.0.2 software.

\section{Results and Discussion}

In relation to the soil density, for all the different uses of the land there was an increase of the density as the depth increased, natural behavior due to the action of the weight of the particles of the soil itself. In relation to soil density, only the native forest area with babassu $\left(1.17 \mathrm{~g} \mathrm{~cm}^{-3}\right)$ presented significant differences in relation to the others for the different depths (Table 2).

\begin{tabular}{|c|c|c|c|c|}
\hline Depth (m) & Native forest & Capoeira & Degraded grassland & CLFI \\
\hline $0.00-0.10$ & $1.17 \mathrm{bC}$ & $1.23 \mathrm{abC}$ & $1.40 \mathrm{aB}$ & $1.32 \mathrm{abC}$ \\
\hline $0.10-0.20$ & $1.36 \mathrm{aA}$ & $1.44 \mathrm{aAB}$ & $1.47 \mathrm{aAB}$ & $1.39 \mathrm{aBC}$ \\
\hline $0.20-0.30$ & $1.31 \mathrm{cAB}$ & $1.34 \mathrm{bcC}$ & $1.49 \mathrm{aAB}$ & $1.38 \mathrm{abBC}$ \\
\hline $0.30-0.40$ & $1.30 \mathrm{bAB}$ & $1.34 \mathrm{bC}$ & $1.58 \mathrm{aAB}$ & $1.46 \mathrm{aB}$ \\
\hline $0.40-0.60$ & $1.30 \mathrm{aAB}$ & $1.35 \mathrm{aC}$ & $1.48 \mathrm{aAB}$ & $1.53 \mathrm{aA}$ \\
\hline $0.60-0.80$ & $1.24 \mathrm{cBC}$ & $1.33 \mathrm{cC}$ & $1.59 \mathrm{aA}$ & $1.53 \mathrm{bA}$ \\
\hline $0.80-1.00$ & $1.28 \mathrm{cAB}$ & $1.48 \mathrm{bcA}$ & $1.51 \mathrm{aAB}$ & $1.53 \mathrm{abA}$ \\
\hline
\end{tabular}

Table 2. Soil density $\left(\mathrm{g} \mathrm{cm}^{-3}\right)$ in areas under different land uses in Maranhense Amazonia, Brazil

Note. Lowercase letters compare mean values of different uses within the same depth. Uppercase letters compare mean values of the same usage at different depths. Means followed by the same letters in the same row or column do not differ from each other based on the Bonferroni test $(\alpha=0.05)$.

The native forest areas and capoeira presented lower values of soil density when compared to the others, mainly in the superficial layers, due to the greater deposition of organic matter and the preservation of its structure, besides a greater variety of natural agents that aid in the process of decrease in density. According to Guariz et al. (2009) as soil deepening occurs, the lower the contribution of organic matter to the aggregation of the particles, which, together with the weight of the overlying layers, the lower penetration of roots and the eluviation of clays results in increased density from soil.

In the degraded pasture and in the CLFI system the mean values of soil density ranged from $1.40 \mathrm{~g} \mathrm{~cm}^{-3}$ to $1.59 \mathrm{~g}$ $\mathrm{cm}^{-3}$ and $1.32 \mathrm{~g} \mathrm{~cm}^{-3}$ to $1.53 \mathrm{~g} \mathrm{~cm}^{-3}$, respectively. In these two areas, there were no significant differences between the depths up to $0.40 \mathrm{~m}$ depth, which results corroborate with those found by Vieira and Klein (2007). However, in spite of the short time of implantation of the integration system, it is possible to perceive that there was a reduction in soil density, mainly in the superficial layers of the soil, probably due to the deposition of the cultural remains and the pasture formed. 
In relation to the total carbon content, it was observed that there were no significant differences between the land uses up to $0.40 \mathrm{~m}$ depth, below which depth there was a significant difference between the CLFI and the other areas (Table 3). This fact may be related to the preparation of the soil for the implantation of the system, contributing to a rapid degradation of the carbon by the microorganisms. Besides, in all areas a usual behavior of the carbon contents was observed, with decreasing values in depth. Campos et al. (2016), comparing different land uses, including pasture and agroforestry, verified that the highest total carbon content in pasture environment, which according to Araújo et al. (2011), is due to the greater accumulation of organic matter due to the greater volume of the grass root system.

Table 3. Total carbon $\left(\mathrm{g} \mathrm{Kg}^{-1}\right)$ in areas under different land uses in Maranhense Amazonia, Brazil

\begin{tabular}{|c|c|c|c|c|}
\hline Depth (m) & Native forest & Capoeira & Degraded grassland & CLFI \\
\hline $0.00-0.10$ & $12.74 \mathrm{aA}$ & $8.61 \mathrm{aA}$ & $10.55 \mathrm{aA}$ & $9.27 \mathrm{aA}$ \\
\hline $0.10-0.20$ & 6.95 & $5.74 \mathrm{aB}$ & $\mathrm{aAB}$ & $6.18 \mathrm{aAB}$ \\
\hline $0.20-0.30$ & 5.40 & $4.46 \mathrm{aC}$ & $\mathrm{aBC}$ & $4.50 \mathrm{aBC}$ \\
\hline $0.30-0.40$ & 4.57 & $4.12 \mathrm{aD}$ & $\mathrm{aBC}$ & $3.73 \mathrm{aCD}$ \\
\hline $0.40-0.60$ & $\mathrm{aDE}$ & $3.65 \mathrm{aE}$ & $\mathrm{aCD}$ & $2.90 \mathrm{bDE}$ \\
\hline $0.60-0.80$ & 3.68 & $3.13 \mathrm{abF}$ & $\mathrm{abDE}$ & 2.09 \\
\hline $0.80-1.00$ & 2.71 & $2.67 \mathrm{aG}$ & 2.11 & $1.61 \mathrm{bE}$ \\
\hline
\end{tabular}

Note. Lowercase letters compare mean values of different uses within the same depth. Uppercase letters compare mean values of the same usage at different depths. Means followed by the same letters in the same row or column do not differ from each other based on the Bonferroni test $(\alpha=0.05)$.

Based on the carbon contents, the carbon stocks presented in Table 4 were calculated, and no significant differences between the different uses were found. The 0.00-0.10 m layers of all treatments presented higher carbon stock due to the higher deposition of organic matter at this depth.

Table 4. Carbon stock $\left(\mathrm{Mg} \mathrm{ha}^{-1}\right)$ in areas under different land uses in Maranhense Amazonia, Brazil

\begin{tabular}{lllllllll}
\hline Depth $(\mathrm{m})$ & \multicolumn{2}{l}{ Native forest } & \multicolumn{2}{l}{ Capoeira } & \multicolumn{2}{l}{ Degraded grassland } & \multicolumn{2}{l}{ CLFI } \\
\hline $0.00-0.10$ & 14.70 & $\mathrm{aA}$ & 10.66 & $\mathrm{aA}$ & 14.76 & $\mathrm{aA}$ & 12.19 & $\mathrm{aA}$ \\
$0.10-0.20$ & 9.46 & $\mathrm{aB}$ & 8.30 & $\mathrm{aB}$ & 9.23 & $\mathrm{aBC}$ & 8.57 & $\mathrm{aABC}$ \\
$0.20-0.30$ & 7.09 & $\mathrm{aC}$ & 5.97 & $\mathrm{aCD}$ & 7.88 & $\mathrm{aC}$ & 6.21 & $\mathrm{aBCD}$ \\
$0.30-0.40$ & 5.93 & $\mathrm{aC}$ & 5.51 & $\mathrm{aD}$ & 7.56 & $\mathrm{aC}$ & 5.45 & $\mathrm{aD}$ \\
$0.40-0.60$ & 11.14 & $\mathrm{aAB}$ & 9.87 & $\mathrm{aA}$ & 12.00 & $\mathrm{aAB}$ & 8.86 & $\mathrm{aAB}$ \\
$0.60-0.80$ & 9.15 & $\mathrm{aB}$ & 8.29 & $\mathrm{aAB}$ & 9.58 & $\mathrm{aABC}$ & 6.39 & $\mathrm{aCD}$ \\
$0.80-1.00$ & 7.05 & $\mathrm{aC}$ & 7.89 & $\mathrm{aBC}$ & 6.39 & $\mathrm{aC}$ & 4.92 & $\mathrm{aD}$
\end{tabular}

Note. Lowercase letters compare mean values of different uses within the same depth. Uppercase letters compare mean values of the same usage at different depths. Means followed by the same letters in the same row or column do not differ from each other based on the Bonferroni test $(\alpha=0.05)$.

The accumulated carbon stocks up to $1.00 \mathrm{~m}$ ranged from $49.52 \mathrm{Mg} \mathrm{ha}^{-1}$ to $64.41 \mathrm{Mg} \mathrm{ha}^{-1}$ and were higher in the native forest with babassu in relation to capoeira and the ILPF system (Figure 1). It is observed that there is a similarity between the carbon stock of native forest with babassu and degraded pasture. Costa et al. (2009) explain that soils under pasture present stocks of $\mathrm{C}$ equal to or greater than those found in native forest environment due to the higher amount of organic matter provided by the roots. Roscoe and Buurman (2003) also did not find significant differences in the $\mathrm{C}$ stock when comparing the natural Cerrado vegetation and a pasture of Brachiaria spp. with 23 years of implantation in an oxisol. 


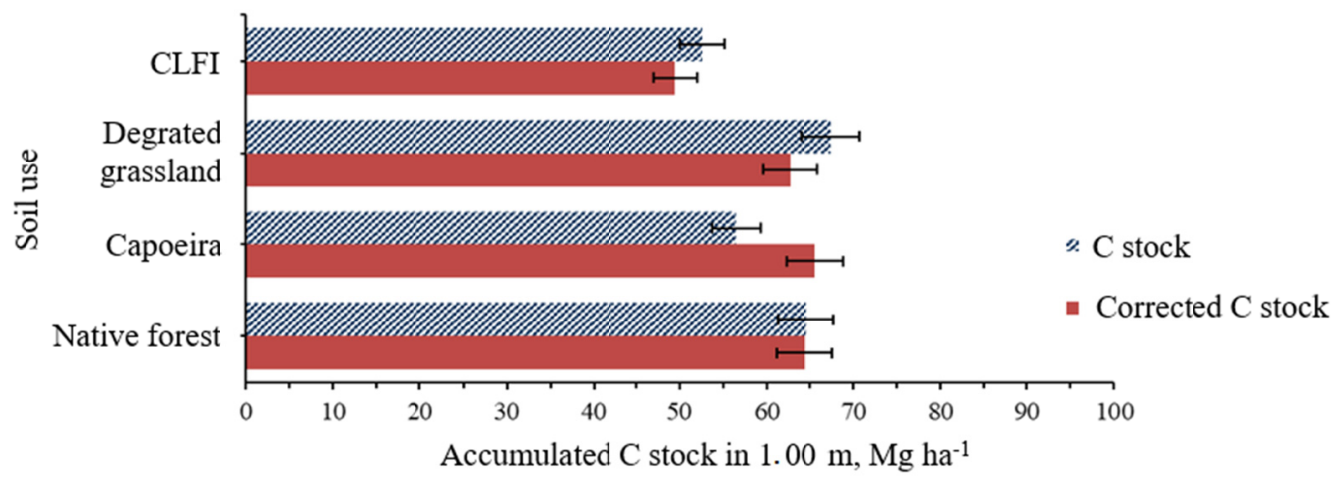

Figure 1. Stocks of $\mathrm{C}$ accumulated up to $1.00 \mathrm{~m}$ and stock of $\mathrm{C}$ corrected by the equivalent mass of soil in different land uses in the Amazonian state of Maranhão, Brazil

Note. Horizontal bars indicate the standard error of the mean $(\mathrm{n}=5)$.

With the correction of accumulated carbon stocks, the averages were $64.41 \mathrm{Mg} \mathrm{ha}^{-1}$ in the native forest, $65.60 \mathrm{Mg}$ $\mathrm{ha}^{-1}$ in capoeira, $62.74 \mathrm{Mg} \mathrm{ha}^{-1}$ in the degraded pasture and 49.50 Mg ha ${ }^{-1}$ in the CLFI system. The variation of uncorrected and corrected carbon stocks was significant only for use with capoeira, which after 20 years of recovery resembles native forest stocks. Probably the accumulated carbon stock in the CLFI system was affected by the management adopted during the implantation, the operations of plowing, grading and leveling, when the soil revolving allowed the rapid decomposition of the organic matter by the exposure of the same and the greater microbial respiratory activity, as also observed by Matias et al. (2009).

Although there were no significant differences in the total $\mathrm{C}$ contents for the $0.00-0.10 \mathrm{~m}$ layer (Table 3 ), it was observed that in the native forest and capoeira, the organic carbon contents associated to the minerals represented, respectively, $85.37 \%$ and $92.78 \%$ of the total C. These values were statistically higher percentages than those sampled with degraded pasture and CLFI with $60.69 \%$ and $64.59 \%$ of the total C content, respectively. Costa et al. (2004) also observed that the labile fractions SOM (soil organic matter) were more sensitive to management changes than total carbon.

In all the layers, when comparing the results, no significant difference was observed between the systems of degraded pasture and CLFI, probably due to the short time of implantation of the system. According to Costa et al. (2004) the no-tillage of the soil and the addition of crop residues on the soil surface under no-tillage adopted in the CLFI system triggers numerous synergic physical, chemical and biological processes, as is the case with processes that lead to increased stability of the aggregates and of the stocks of organic matter in the soil.

In all uses, the organic fraction was lower than the organomineral fraction, different from the results of the physical fractionation of the samples of a dystrophic Yellow Red Latosol described by Martins et al. (2009). This trend observed in all the sampled soil profile, with greater representativity of $\mathrm{C}$ contents in the organomineral fraction, is in agreement with Santos (2008), who found greater accumulations of organomineral C in Amazonian soils of the same texture. This author states that the physical fractions of soil organic matter (SOM) are influenced by a number of factors, but the climate acts as a strong component where the content of SOM and N increases according to the increase of humidity and decreases with increase in temperature. In the studied region dominates hot and humid climate with drought and rainy season, and annual average temperatures are high year-round between $295.45 \mathrm{~K}$ and $306.65 \mathrm{~K}$. 

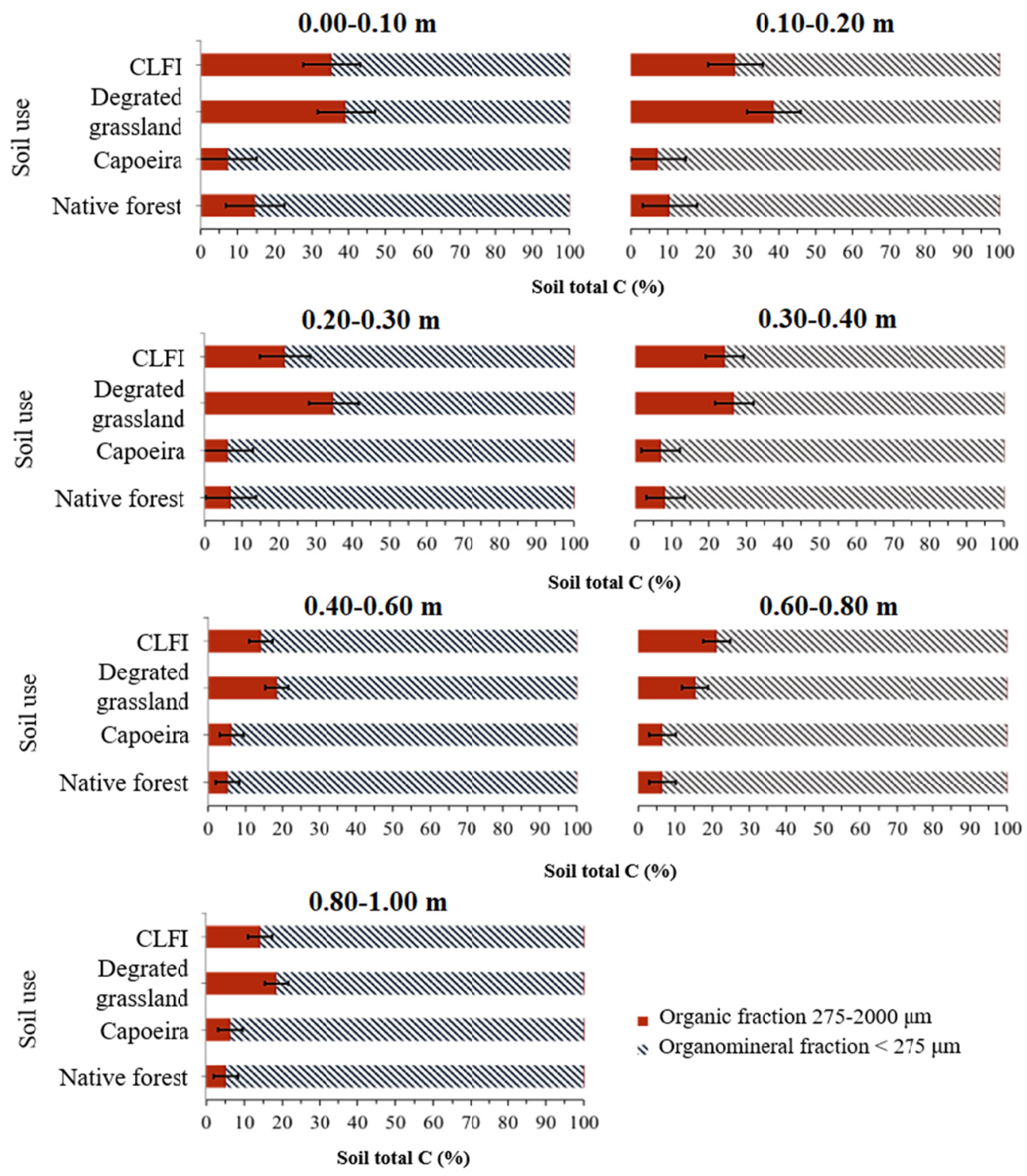

Figure 2. Relative participation of organic and organomineral fractions in total soil C content in different uses at seven depths in the Maranhense Amazon region, Brazil

Note. Horizontal bars indicate the standard error of the mean $(\mathrm{n}=5)$.

\section{Conclusions}

The conversion of native forest and capoeira to pasture provided an increase in soil density. Despite this, there was no difference in carbon content and carbon stock in the soil. In relation to the accumulated carbon stock, the native forest and degraded pasture were the ones that obtained the highest levels, followed by the capoeira and the CLFI system. Despite similar values of carbon stocks in the uses with degraded pasture, native forest and capoeira, the proportions of the organomineral fractions were higher in the native forest and capoeira.

\section{Acknowledgements}

The authors thank to the Foundation for Supporting Research and Scientific and Technological Development of Maranhão (FAPEMA) for funding the Project, through the Universal Call for Research Support 14/2015. In addition, we thank for the provision of scientific initiation grants during the years of project development.

We also thank to the Brazilian Agricultural Research Corporation (EMBRAPA), for the technical and operational contribution during the research development. 


\section{References}

Araújo, E. A., Ker, J. C., Mendonça, E. S., Silva, I. R., \& Oliveira, E. K. (2011). Impact of forest-pasture conversion on stocks and dynamics of soil carbon and humic substances in the Amazon. Acta Amazônica, 41(1), 103-114. https://doi.org/10.1590/S0044-59672011000100012

Balbino, L. C., Cordeiro, L. A. M., Oliveira, P., Kluthcouski, J., Galerani, P. R., \& Vilela, L. (2012). Agricultura sustentável por meio da Integração Lavoura-pecuária-floresta (ILPF). Informações Agronômicas, 138(7), $1-14$.

Campos, M. C. C., Soares, M. D. R., Nascimento, M. F., \& Silva, D. M. P. (2016). Carbon storage in soil and aggregates of Inceptisols under different land use management systems in southern Amazonas. Revista Ambiente e Água, 11(2), 339-349. https://doi.org/10.4136/ambi-agua.1819

Christensen, B. T. (1992). Physical fractionation of soil and organic matter in primary particle size and density separates. Advances in Soil Science, 20, 1-90. https://doi.org/10.1007/978-1-4612-2930-8_1

Conceição, P. C., Bayer, C., Dieckow, J., \& Santos, D. C. (2014). Fracionamento físico da matéria orgânica e índice de manejo de carbono de um Argissolo submetido a sistemas conservacionistas de manejo. Ciência Rural, 44(5), 794-800. https://doi.org/10.1590/S0103-84782014005000004

Costa, F. S., Bayer, C., Albuquerque, J. A., \& Fontoura, S. M. V. (2004). No-tillage increases soil organic matter in a South Brazilian oxisol. Ciência Rural, 34(2), 587-589. https://doi.org/10.1590/S0103-84782004000 200041

Costa, O. V., Cantarutti, R. B., Fontes, L. E. F., Costa, L. M., Nacif, P. G. S., \& Faria, J. C. (2009). Soil carbon stocks under pasture in costal tableland areas in southern Bahia state, Brazil. Revista Brasileira de Ciência do Solo, 33(5), 1137-1145. https://doi.org/10.1590/S0100-06832009000500007

Dias-Filho, M. B. (2014). Recuperação de pastagens degradadas na Amazônia: Desafios, oportunidades e perspectivas. In R. H. R. Sambuichi, et al. (Eds.), Políticas agroambientais e sustentabilidade: Desafios, oportunidades e lições aprendidas (pp. 149-169). INPE, Brazil.

DIEESE. (2001). Estatísticas do meio rural 2010-2011 (4th ed.). São Paulo: DIEESE, NEAD, MDA.

Donagema, G. K. (2011). Manual de métodos de análises de solo (p. 132). Rio de Janeiro, RJ: Embrapa Solos.

Ellert, B. H., \& Bettany, J. R. (1995). Calculation of organic matter and nutrients stored in soils under contrasting management regimes. Canadian Journal of Soil Science, 75(4), 529-538. https://doi.org/10.4141/cjss95-075

Guariz, H. R., Campanharo, W. A., Picoli, M. H. S., Cecílio, R. A., \& Hollanda, M. P. (2009). Variação da umidade e da densidade do solo sob diferentes coberturas vegetais. Anais do XIV Simpósio Brasileiro de Sensoriamento Remoto. Rio Grande do Norte, Natal, Brazil.

INPE (Instituto de Pesquisa Econômica Aplicada). (2017). Taxas anuais do desmatamento-1988 até 2017 (Km²/ano). PRODES. Retrieved from http://www.obt.inpe.br/prodes/taxas_prodes.htm

La Rovere, E. L. (2017). Low-carbon development pathways in Brazil and Climate Clubs. Wiley Interdisciplinary Reviews-Climate Change, 8(1), 439-445. https://doi.org/10.1002/wcc.439

Martins, E. L., Coringa, J. E. S., \& Weber, O. L. S. (2009). Organic carbon in granulometric fraction and in humic substances of a Brazilian Oxisol under different land use systems. Acta Amazônica, 39(3), 655-660. https://doi.org/10.1590/S0044-59672009000300021

Matias, M. C. B. S., Salviano, A. A. C., Leite, L. F. C., \& Araújo, A. S. F. (2009). Microbial biomass and C and $\mathrm{N}$ stocks in soil under different management systems in the 'Cerrado' of Piauí State. Acta Scientiarum Agronomy, 31(3), 517-521. https://doi.org/10.4025/actasciagron.v31i3.687

Rego, C. A. R. M., Reis, V. R. R., Wander, A. E., Cantanhede, I. S. L., Costa, J. B., Muniz, L. C., Costa, B. P., \& Herrera, J. L. L. (2017). Cost Analysis of Corn Cultivation in the Setup of the Crop-Livestock-Forest Integration System to Recover Degraded Pastures. Journal of Agricultural Science, 9(6), 168-174. https://doi.org/10.5539/jas.v9n6p168

Roscoe, R., \& Buurman, P. (2003). Tillage effcts on soil organic matter in density fractions of a Cerrado Oxisol. Soil Tillage Research, 70(2), 107-119. https://doi.org/10.1016/S0167-1987(02)00160-5

Santos, C. H. (2008). Alterações na dinâmica da matéria orgânica e dos atributos químicos e físicos induzidas por diferentes usos de um solo de Colorado do Oeste-RO (Master's thesis, Universidade Federal de Mato Grosso, Cuiabá, Mato Grosso, Brazil). 
Santos, H. G. Dos, Jacomine, P. K. T., Anjos, L. H. C. Dos, Oliveira, V. A. De, Lumbreras, J. F., Coelho, M. R., ... Oliveira, J. B. De. (2013). Sistema Brasileiro de Classificação de Solos (3rd ed., p. 353). Rio de Janeiro, RJ: Embrapa Solos.

SEPLAN (Secretaria de Estado do Planejamento e Orçamento). (2013). Atlas do Maranhão. Secretaria de Estado do Planejamento e Orçamento, Núcleo Geoambiental. São Luís, Maranhão, Brasil.

Signor, D., Zani, C. F., Paladini, A. A., Deon, M. D., \& Cerri, C. E. P. (2014). Estoques de carbono e qualidade da matéria orgânica do solo em áreas cultivadas com cana-de-açúcar. Revista Brasileira de Ciência do Solo, 38(5), 1402-1410. https://doi.org/10.1590/S0100-06832014000500005

Vieira, M. L., \& Klein, V. A. (2007). Propriedades físico-hídricas de um Latossolo Vermelho submetido a diferentes sistemas de manejo. Revista Brasileira de Ciência do Solo, 31(6), 1271-1280. https://doi.org/ $10.1590 / \mathrm{S} 0100-06832007000600006$

\section{Copyrights}

Copyright for this article is retained by the author(s), with first publication rights granted to the journal.

This is an open-access article distributed under the terms and conditions of the Creative Commons Attribution license (http://creativecommons.org/licenses/by/4.0/). 